\title{
Management of hard coal mining and processing wastes in Poland
}

\section{Introduction}

Poland has an extensive mining industry, contributing significantly to the total amount of industrial wastes generated in the country. However, the level of industrial wastes generated in Poland has declined from 143.9 million $\mathrm{Mg}$ in 1990 to 125.5 million $\mathrm{Mg}$ in 2000, and further to 113.5 million $\mathrm{Mg}$ in 2010 before climbing back to 123.1 million $\mathrm{Mg}$ in 2012. The quantity of utilised wastes grew from 77.1 million $\mathrm{Mg}$ (53.6\%) in 1990 to 89.0 million $\mathrm{Mg}(72.3 \%)$ in 2012 . The majority of these wastes are generated in the three southern voivodeships of Śląskie (30\%), Dolnośląskie (28\%), Łódzkie (7\%), and Małopolskie (6\%) (GUS 2013).

Wastes from mining and processing (waste code 01) are the largest group of wastes generated and deposited in Poland. According to official data, in 2012 some 63.8 million Mg of mining and processing wastes were generated, amounting to approx. $53 \%$ of total industrial wastes produced. The three main types of such wastes in Poland are wastes from the mining and processing of hard coal, wastes from the mining and processing of non-ferrous metal ores, and wastes from rock minerals' extraction (GUS 2013; Galos et al. 2009).

Wastes from the mining and processing of hard coal traditionally constitute the most important group, thus this paper will concentrate especially on them. In the mining and processing of non-ferrous metal ores, amounts of wastes generated varied between 30 and

* Professor, ** M.Sc. Eng., Mineral and Energy Economy Research Institute, Polish Academy of Sciences, Krakow, Poland; e-mail: kgalos@min-pan.krakow.pl 
35 million Mg per year, with some reduction in recent years to 29.8 million $\mathrm{Mg}$ in 2012, and approx. $66 \%$ of these being utilised in hydrotechnical engineering, i.e. for construction of barriers and sealing of the Żelazny Most settling pond (GUS 2013). Flotation wastes from copper ores processing at KGHM ore processing plants constituted a majority of them (about 28.7 million $\mathrm{Mg}$ in 2012, i.e. 96\%). Flotation wastes from the processing of $\mathrm{Zn}-\mathrm{Pb}$ ores constituted $6 \%$, while mining wastes amounted to $1 \%$. Wastes coming from the extraction and processing of rock minerals as reported by the Central Statistical Office are substantially underestimated. According to this official information, the generation of wastes from the mining of rock minerals varies between 1.3-3.6 million Mg per year (only 1.3 million Mg in 2012), and the majority of them are utilised. However, it is estimated that the total volume of these wastes varies between 8 and 11 million Mg per year, while the level of their utilisation does not exceed $30 \%$. The most important types of wastes classified into this group are wastes obtained during the extraction and processing of compact rocks (limestone, dolomite, sandstone, magmatic rocks), as well as extraction of clays, sand, and gravel. Their most important applications are civil engineering and crushed aggregates, in addition to the recovery of lower quality kaolin or feldspar-quartz raw material, Ca, and Ca-Mg for fertilizers (Galos et al. 2009).

\section{Sources and types of hard coal mining and processing wastes}

The amount of waste generated in the hard coal industry is gradually declining, from 50-60 million Mg per year over 20 years ago to approx. 40 million Mg in 2000, and under 30 million $\mathrm{Mg}$ in 2010. Over the following two years, the amount of hard coal waste rose to 33.7 million Mg by 2012, with 28.6 million Mg of this being utilised. Roughly 4.8 million $\mathrm{Mg}$ of such waste was generated in 2012 by the activity of the only mine in the Lublin Coal Basin - the Bogdanka mine - while the rest resulted from production in the mines located in the Upper Silesia Coal Basin. The majority of the waste (roughly 93\%) is obtained during the processing of heavy liquids, jiggers, and slurry circulation. Flotation wastes make up $6 \%$ of the total amount, while mining wastes comprise the rest. A high level of economic utilisation of hard coal industry wastes is reported (exceeding even $90 \%$ ). However, only about $30 \%$ of the waste is utilised in industrial applications, while over $70 \%$ is applied to ground levelling and other engineering works (GUS 2013; Galos et al. 2009).

Wastes from the mining and processing of hard coal come from barren sedimentary Carboniferous rocks, which are extracted - as ripping material - together with hard coal seams. Some additional amount of such materials comes from preparatory mining works, where so-called "stone workings" are built (Zorychta and Burtan 2008). These wastes, in general, can be divided into two main groups:

- Mining wastes - constituting up to $20 \%$ of the total amount of hard coal wastes, coming directly from preparatory mining works, with highly variable quality parameters depending on rock types and geological conditions of extracted deposits; granulation of such wastes is inhomogeneous, reaching up to $500 \mathrm{~mm}$. 
- Processing wastes - coming from hard coal processing, depending on the type of processing equipment used and the applied technologies, these can be divided into three subgroups:

- coarse-grained wastes from dense medium gravity separation - homogeneous mineral composition, granulation 20-200 mm, coal content 5-15\%, sulphur content $<1 \%$, humidity $4-6 \%$,

- fine-grained wastes from jiggers - homogeneous mineral composition, granulation under $20 \mathrm{~mm}$, higher coal content, sulphur content, and humidity than in coarse-grained wastes,

- very fine-grained flotation wastes - high content of coal, sulfur, and high humidity, with presence of residues of flotation reagents and flocculants (Lutyński and Blaschke 2009; Galos et al. 2009).

Regarding petrographic types, the main components of coal wastes are - in variable amounts - claystone, clay shales, mudstone, sandstone, and, rarely, conglomerate, with the leading share of claystone. Sandstone is rare in processing wastes; it is more often found in mining wastes. Conglomerate can occur only in mining wastes.

Coal wastes in individual mines exhibit variable petrographic composition and content of combustible particles. This results from the geological setting and the type of rock accompanying coal seams, as well as from processing technology. For example, claystone and clay shale dominate in barren rocks in mines near Jastrzębie or Bytom $(>90 \%)$. In the eastern part of the Upper Silesian Coal Basin, sandstone content can reach 70\%. Content of combustible particles can reach 10\% (Potempa and Szlugaj 2007; Koperski and Lech 2007; Szlugaj et al. 2008).

Processing wastes from dense medium gravity separators and jiggers constitute the majority of the total amount of hard coal mining and processing wastes (approx. 90\%). Flotation wastes constitute around $5 \%$, while mining wastes make up the rest. The degree of economic use of coal wastes has recently risen to over $90 \%$, but only about $30 \%$ of these wastes found industrial use, while over $70 \%$ was used for ground levelling and engineering works. Moreover, according to official data some 478 million $\mathrm{Mg}$ of coal wastes are deposited in various dumps, while the real amount of such wastes may be as much as two to three times higher (GUS 2013; Galos 2003).

In spite of declining coal waste quantities, new technologies allowing the utilization of coal wastes are still under development. It is possible to:

- lead processing to directly obtain not only coal, but also a second product (e.g. aggregates), and/or

- recover coal mining and processing wastes to obtain aggregates and other raw materials for building materials' production (Sokół and Tabor 1996; Gawenda and Olejnik 2008; Baic and Witkowska-Kita 2011; Baic 2013; Cała, ed. 2013).

Coarse-grained wastes are the most interesting due to their wide range of possibilities for industrial use. Currently, their main directions of use are:

- engineering, hydrotechnical, and road construction including the production of aggregates for such purposes (Góralczyk et al. 2007; Góralczyk et al. 2009), 
- production of raw materials for building materials - cement, building ceramics (SPC 2014),

- recovery of coal and production of low calorific materials for power plants,

- use of such wastes as filling material for backfilling of underground workings (Galos et al. 2009; Baic et al. 2011).

\section{Production of aggregates for engineering, hydrotechnical applications, and road construction from coal wastes}

Two main areas of coal waste use for aggregates production are (Galos and Nieć 2007; Smakowski et al. 2014):

- production of aggregates with variable graining and mechanical parameters on the basis of raw coal wastes,

- production of lightweight aggregate (shale gravellite) on the basis of self-burnt coal shale.

\subsection{Production of aggregates from raw coal wastes}

Haldex S.A. is the main company dealing with the complex utilization of coal wastes in the Upper Silesia region. In 2008 the company became a part of the Kompania Węglowa S.A. capital group (the largest hard coal producer in Poland). Now, it is the sole operator of coal wastes coming from mines belonging to Kompania Węglowa S.A. Over 50 years of activity, the plants of Haldex S.A. processed over 150 million Mg of coal wastes. From these wastes approx. $10 \%$ of the coal was recovered. Around $6 \%$ constituted coal shale for building ceramics, roughly $7 \%$ was coal shale for cement production, another $7 \%$ were materials for engineering and land reclamation works, and 3\% were materials for the production of lightweight aggregates (shale gravellite). The remaining $67 \%$ of the wastes were used as material for backfilling in underground coal mines (Koperski et al. 2008).

Recently, Haldex S.A. started to be an important producer of quality aggregates from coal wastes from the mines of Kompania Weglowa S.A. Such aggregates exhibit variable graining, being composed of varying shares of claystone, mudstone, and sandstone. Currently, such production is carried out in four plants of Haldex S.A. - the Z-2 Szombierki in Bytom (since 1963), Z-3 Makoszowy in Zabrze (since 1965), and Z-6 Brzezinka in Mysłowice-Brzezinka (since 1980); these have a processing capacity of about 2,800 tpd each, and - since 2011 - the new Z-12 Panewniki plant in Mikołów added another 5,000 tpd of capacity.

Each Haldex plant consists of the following: 1 - preparation of input $(0-200 \mathrm{~mm}$ coal wastes); 2 - initial classification into grain classes $<80 \mathrm{~mm}$ and $>80 \mathrm{~mm}$ (additionally crushed); 3 - second stage of classification on vibrating screens into classes $<45 \mathrm{~mm}$ and $>45 \mathrm{~mm}$ (additionally crushed); 4 - classification in hydrocyclones with the use of dense 
media, followed by washing and dewatering where thermal hard coal of $0-20 \mathrm{~mm}$ and $20-45 \mathrm{~mm}$ is obtained; and 5 - thickening and classification of wastes from hydrocyclones, where $0-3 \mathrm{~mm}$ ceramic shale and 3-45 $\mathrm{mm}$ aggregate are obtained (Kucharzyk 2004).

Aggregate of 3-45 $\mathrm{mm}$ obtained in the above mentioned Haldex plants is commonly a mixture of Carbonaceous claystone, clay shales, mudstone, and sandstone, with a predominance of clay shales and claystones and a small share of sandstone $(<10 \%)$. This aggregate exhibits variable water absorption and - commonly - weak freeze resistance. It can be used in engineering works (road construction, hydrotechnical construction), for land reclamation, for construction of landfills, and for backfilling of underground workings. Due to weak freeze resistance, such aggregate can be used in road construction only after stabilization with the use of cement, active fly ash, or granulated blast furnace slag. Some modifications in the Haldex plant in recent years made it possible to change the assortment of produced aggregates, with separation of coarse-grained aggregates (Table 1). Total production of aggregates in the plants of Haldex S.A. reached 1.8 million $\mathrm{Mg}$ in 2008, including around $30 \%$ of aggregates $>31.5 \mathrm{~mm}$ (Koperski et al. 2008), and - after commencement of the Z-12 Panewniki plant - their total capacities exceeded 3.0 million $\mathrm{Mg}$ per year in 2013.

Haldex S.A. also started to process wastes entirely from preparatory mining works (or mixed with coal processing wastes). These wastes are directed to mobile crushing-sieving units (so-called "WKS"), where aggregates with granulation consistent with customers' expectations can be provided. The company opened two such units, with a daily capacity of 2,000 Mg each - 1. WKS Knurów, near the Aniołki shaft of the Knurów hard coal mine

Table 1. Aggregates from coal wastes produced in the plants of Haldex S.A.

Tabela 1. Kruszywa z odpadów powęglowych produkowane w zakładach Haldex S.A.

\begin{tabular}{|c|c|c|c|c|c|}
\hline Granulation $[\mathrm{mm}]$ & Z-2 Szombierki & Z-3 Makoszowy & Z-6 Brzezinka & Z-12 Panewniki & WKS Rydułtowy \\
\hline $0-31.5$ & $\times$ & $\times$ & $\times$ & & $\times$ \\
\hline $31.5-63$ & & & & & $\times$ \\
\hline $31.5-90$ & & & & & \\
\hline $40-90$ & & & $\times$ & & \\
\hline $10-31.5$ & & & $\times$ & & \\
\hline $2-100$ & & & & $\times$ & \\
\hline+100 & & & & $\times$ & \\
\hline $0-63$ & & $\times$ & & & $\times$ \\
\hline $0-200$ & $\times$ & $\times$ & & & $\times$ \\
\hline $63(100)-150(200)$ & $\times$ & $\times$ & $\times$ & & \\
\hline
\end{tabular}

Source: Company's information 
(since 2007), and 2. WKS Rydułtowy, in the Rydułtowy Ruch II Anna hard coal mine (since 2008). Total aggregates production in these units can reach up to 0.9 million $\mathrm{Mg}$ per year.

\subsection{Production of shale gravellite aggregates}

Shale gravellite is artificial, lightweight aggregate obtained in the course of thermal processing (sintering) of raw coal shale, or from the mechanical processing of self-burnt coal shale from old dumps.

For decades, shale gravellite was manufactured by sintering raw coal shale, mainly in the Lightweight Aggregates Production Plant in Siemianowice Śląskie, belonging to Haldex S.A. Its production sometimes exceeded 200,000 Mg per year (Mokrzycki ed. 1992). Such production was abandoned in the early 1990s due to high production costs (energy costs) and environmental problems (gas and dust emissions).

Shale gravellite can also be obtained from self-burnt coal shale from old dumps (so-called "red shale"). Self-burning of coal shales occurred over periods of years or even decades (Nowak 2014). To obtain lightweight aggregates from such material, simple processes of crushing and classification are employed, analogous to processes of natural crushed aggregates production. Since the 1990s, production of these shale gravellite aggregates was intensified. Self-burnt shale was obtained from old dumps in Upper Silesia, e.g. in Pszów, Radlin, Rybnik, Gliwice, Zabrze, Ruda Śląska, Chorzów, Katowice, Bytom, Czeladź, Będzin, and Dąbrowa Górnicza, as well as in Nowa Ruda in Lower Silesia. From the dumps, lightweight aggregates of various granulation are obtained, from $0-3 \mathrm{~mm}$ to

Table 2. Main producers of shale gravellite aggregates in Poland

Tabela 2. Główni producenci kruszyw łupkoporytowych w Polsce

\begin{tabular}{|c|c|}
\hline Company & Assortment of aggregates produced (mm) \\
\hline Barosz-Gwimet Marklowice & $0-10,10-16,16-31.5,0-31.5,0-63,31.5-63,63-100,100-350$ \\
\hline Foreko Śląsk Bytom & $0-10,0-63,31.5-63,63-200$ \\
\hline Wirex Będzin & $0-10,0-31.5,31.5-63,63-90$ \\
\hline IBC Katowice & $0-31.5,31.5-63,0-63,60-200$ \\
\hline Stef-Pol Rybnik & $0-3,0-16,0-31.5,0-63,4-16,16-31.5,31.5-63$ \\
\hline Azas Będzin & $30-60,80-120$ \\
\hline Trakt Gliwice & $0-10,0-63$ \\
\hline $\begin{array}{c}\text { Slag Recycling Kraków } \\
\text { (dump in Nowa Ruda) }\end{array}$ & $0-63,31.5-63,63-250,>250$ \\
\hline Tercharpol Siemianowice Śląskie & $0-10,0-31.5,0-63$ \\
\hline
\end{tabular}

Source: producers' data 
16-63 mm, sometimes even $125-350 \mathrm{~mm}$. They are used primarily in the construction of internal roads and storage yards of industrial factories, parking lots, etc. Their use in public road construction is limited due to increased water absorption values. There is a lack of exact data on the level of production of shale gravellite aggregates, as such production is commonly carried out by small and very small companies. It is estimated that their total production amounts to at least $500,000 \mathrm{Mg}$ per year, but it is possible that it sometimes exceeds even 1 million Mg per year (Galos et al. 2009). The main producers are shown in Table 2.

\section{Production of coal shale for cement and building ceramics}

The chemical composition of coal shale $0-3 \mathrm{~mm}$ obtained in Haldex S.A. plants is predominantly similar to brick clay, but unfortunately possesses a higher content of combustible particles, restricting its use in the conventional methods of building ceramics' production. Such coal shale, depending on the place of origin, the means of receiving, and granulation, can have an average calorific value ranging between 1,200 and $4,500 \mathrm{~kJ} / \mathrm{kg}$. Near the upper limit of calorific values, the thermal energy contained in this shale exceeds by several times the amount of energy to be utilised during the process of building ceramics' production. This parameter restricts the usage of high calorific coal shale in the production of wall-building ceramics (Galos et al. 2009).

At present, coal shale - mainly Haldex coal shale - is utilised in small amounts as a supplementary component (20-30\% of the batch), decreasing the plasticity and drying sensitivity of the body in the technology of plastic forming of building ceramics in a few plants in Upper Silesia. The advantage of its usage is the lower energy consumption in the production of building ceramics due to its significant combustible particles content. It is estimated that total utilization of such material in building ceramics' production does not exceed a level of 50,000 Mg per year.

The Ekoklinkier plant near the Bogdanka hard coal mine in the Lublin Coal Basin (eastern Poland) is an example of the successful implementation of building ceramic production exclusively from clayey coal processing waste. This highly automated factory of yellow-brownish facade bricks (annual capacity 20 million units), built on the basis of a license granted by the French company Occidental Industries, was opened in 1996. Coal shale (grain size $20-80 \mathrm{~mm}$ ) from the coal processing plant in the Bogdanka coal mine is applied in this plant. The production process is energy saving mainly due to the utilization of residual coal contained in the applied coal shale. This plant is the only European plant and the second in the world which has applied such technology and raw materials.

The cement industry is the most important user of Haldex coal shale. The industry consumes 150,000-200,000 Mg per year of this raw material. Coal shale is applied as an important aluminium- and silica-rich material. Transportation cost to cement plants is the most significant barrier which limits widespread utilization of coal shale in the cement 
industry. This is why it is used only in the cement plants in the Opole region. Lower fuel consumption in the process of cement clinker production is a significant advantage of the use of coal shale (Galos et al. 2009).

\section{Recovery of coal and production of low calorific materials for power plants}

Coal mining wastes are a significant source for coal recovery because - depending on their type - they may contain $10-15 \%$ of coal substance or more. For decades, coal recovery from coal mining wastes has been undertaken by Haldex S.A. Coal produced in Haldex S.A. processing plants is recovered as fine coal $(0-20 \mathrm{~mm})$ and pea coal $(20-45 \mathrm{~mm})$. It is a steam coal (type 31.1 and 31.2), with an average calorific value of $22-23 \mathrm{MJ} / \mathrm{kg}$, ash content of $18-20 \%$, sulphur content $0.7-0.8 \%$, and moisture $8-12 \%$. The annual coal production in Haldex S.A. plants varies between 120,000 and $170,000 \mathrm{Mg}$ per year. During the last 50 years Haldex S.A. recovered some 17 million Mg of such coal (Kucharzyk 2004; Galos et al. 2009).

Besides Haldex S.A., coal recovery is also a component of activity of a few other, smaller companies in the Upper Silesia region, such as Gwarex Polska in Świętochłowice (2 million tonnes of coal recovered since 1991), and Polho in Czerwionka which, since 1993, has recovered coal from the Dębieńsko coal mine dump site.

Coal mud also started to be utilised for the production of granulated mud, being a low calorific material for power plants. The production process involves proper mixing and granulating. The installations are located directly on coal mud dump sites, eliminating the transportation costs of wastes and allowing for the production of cheaper products. The applied granulation technology makes it possible to improve the basic parameters of the produced fuel, i.e. to reduce moisture and to increase calorific value.

The production of granulated mud has been carried out by Haldex S.A. since 1995 in the Z-3 Makoszowy plant in Zabrze. The production capacity amounts to 20,000 Mg per month. Additional plants were opened by Haldex S.A. in the Piekary coal mine in Piekary Śląskie (since 2006, production capacity of 20,000 Mg per month), and in the Brzeszcze coal mine in Brzeszcze (since 2008, production capacity of $12,000 \mathrm{Mg}$ per month). The granulated mud from the Haldex plants has calorific values of from $10-12 \mathrm{MJ} / \mathrm{kg}$ to even better than $18 \mathrm{MJ} / \mathrm{kg}$.

Recently, Tauron Wydobycie (previously Południowy Koncern Węglowy - PKW) also started to utilize coal mud. The developed technology of coal mud agglomeration (with participation of binder), followed by the granulation of such material, make it possible to produce low calorific agglomerated mud granulate. Its calorific value is relatively low about $9.3 \mathrm{MJ} / \mathrm{kg}$ - from the Sobieski coal mine, and only $5.5 \mathrm{MJ} / \mathrm{kg}$ - from the Janina coal mine (Szymkiewicz et al. 2009). The production capacity amounts to ca. $60-100 \mathrm{Mg}$ per hour. i.e. 20,000-30,000 Mg per month (Wróbel et al. 2012). 


\section{Use of coal wastes for backfilling underground workings}

Utilization of coal wastes as a component in the hydraulic backfilling of underground workings is a significant direction for the use of such wastes; up to 3 million Mg per year of coal wastes are utilised in this way. Although this use of coal wastes should be preferred, due to technical and mainly economic reasons there has been no tendency toward the growth of such use in recent years.

The technical possibilities of using coal mining wastes as a component of dry-pneumatic or hydraulic backfilling material exist in about 30 Polish coal mines in the Upper Silesia Coal Basin which are equipped with backfilling installations. In hydraulic backfilling, coal wastes are used as a supplement to basic backfilling material, i.e. quartz sand (lately also some wastes from power plants). Their share of up to $50 \%$ of the total amount of backfilling material does not cause a decrease in backfilling effectiveness (Galos et al. 2009).

\section{Conclusions}

Mining and processing wastes are the largest group of industrial wastes generated and deposited in Poland (currently over 60 million Mg per year). Wastes from hard coal mining and processing traditionally constitute the most important group among them. Their production has been declining, from 50-60 million Mg per year over 20 years ago to 29-33 million Mg per year recently, with approx. 85\% being utilised. Hard coal wastes are divided into two main groups - mining wastes constituting up to $20 \%$ and coming directly from preparatory and productive mining works, and processing wastes divided into coarse-grained wastes from dense medium gravity separation, fine-grained wastes from jiggers, and very fine-grained flotation wastes.

Coarse-grained wastes are the most interesting group due to their many possibilities for industrial use. Currently, the main directions of their application are engineering, hydrotechnical applications, road construction (with aggregates production), production of cement or building ceramics, recovery of coal, and as backfilling material. For aggregates production, two types of such wastes are used - raw coal wastes and self-burnt coal shale. The most important producer of aggregates from raw coal wastes is Haldex S.A., which has four processing plants delivering various aggregates, coal shale for cement or ceramics, and recovered coal, and two crushing-sieving units delivering aggregates only. The company's total aggregates production exceeds 3 million $\mathrm{Mg}$ per year. Production of shale gravellite aggregates from self-burnt coal shale from old dumps has intensified since the 1990s. Such production is carried out by a dozen or so small or very small companies, with a total production volume of at least 0.5 million Mg per year. Raw coal shale is used for building ceramics and cement clinker manufacture, but its total consumption does not exceed 0.3 million Mg per year. Coal recovery from coal wastes, as well as granulated coal mud 
production, are also important directions of such waste's utilization. Annual coal recovery, mostly by Haldex Co. plants, currently exceeds 0.15 million Mg per year, while granulated coal mud production in three plants of Haldex and two plants of Tauron Wydobycie can be a few times higher $-0.6-0.7$ million $\mathrm{Mg}$ per year.

In the coming years, shale gravellite aggregates' production, as well as raw coal shale consumption in cement and ceramics manufacture, are not expected to rise significantly. On the other hand, further development is possible in cases of coal recovery accompanied by the production of aggregates from raw coal wastes. However, sales of such low quality aggregates will be limited mainly to applications in constructing road embankments and river embankments in the immediate vicinity of the production plant.

\section{REFERENCES}

Baic, I. 2013. Technologie zagospodarowania odpadów z górnictwa węgla kamiennego - wyniki projektu FORESIGHT OGWK. Rocznik Ochrona Środowiska, 15, s. 1899-1915.

Baic, I. and Witkowska-Kita, B. 2011. Technologie zagospodarowania odpadów z górnictwa węgla kamiennego diagnoza stanu aktualnego, ocena innowacyjności i analiza SWOT. Rocznik Ochrona Środowiska, 13, s. $1315-1327$.

Baic et al. 2011 - Baic, I., Witkowska-Kita, B., Blaschke, W., Lutyński, A., Kozioł, W. and Piotrowski, Z. 2011 Wpływ wybranych czynników na rozwój innowacyjnych technologii zagospodarowania odpadów pochodzących z górnictwa węgla kamiennego metodą krzyżowej analizy wpływów. Rocznik Ochrona Środowiska, 13 , s. 1339-1359.

Cała, M., ed. 2013. Mining Waste Management in the Baltic Sea region. Min-Novation project. Kraków: Wyd. AGH, $264 \mathrm{~s}$.

Galos, K. 2003. Mineral waste raw materials and their importance in the domestic management of mineral raw materials. Gospodarka Surowcami Mineralnymi-Mineral Resources Management, 19(4), s. 15-28.

Galos, K. and Nieć, M. 2007. Źródła, technologie pozyskiwania i gospodarka kruszywami sztucznymi [W:] Ney R. (red.) Surowce Mineralne Polski. Surowce skalne. Kruszywa mineralne. Kraków: IGSMiE PAN.

Galos et al. 2009 - Galos, K., Hycnar, E., Lewicka, E., Ratajczak, T., Szlugaj, J. and Wyszomirski, P. 2009. Mineralne surowce odpadowe z górnictwa i przeróbki [W:] Ney R., red. Surowce mineralne Polski. Mineralne surowce odpadowe. Kraków: IGSMiE.

Gawenda, T. and Olejnik, T. 2008. Produkcja kruszyw mineralnych z odpadów powęglowych w Kompanii Węglowej S.A. na przykładzie wybranych kopalń. Gospodarka Surowcami Mineralnymi - Mineral Resources Management 24(2/1), s. 27-42.

Góralczyk et al. 2009 - Góralczyk, S., Mazela, A., Stankiewicz, J. and Filipczyk, M. 2009. Przywęglowa skała płona - odpad czy surowiec? Pr. Nauk. Inst. Górn. Pol. Wr. 125, s. 95-104.

Góralczyk et al. 2007 - Góralczyk, S., Mazela, A. and Stankiewicz, J. 2007. Badania fizykomechaniczne właściwości skał przywęglowych. Pr. Nauk. Inst. Górn. Pol. Wr. 119, s. 45-56.

GUS 2013. Ochrona Środowiska 2013. Warszawa: Główny Urząd Statystyczny (GUS), 532 s.

Koperski et al. 2008 - Koperski, T., Cukiernik, Z. and Wiśniewski, J. 2008. Aspekty i uwarunkowania związane z przekształcaniem odpadów wydobywczych w produkty [W:] Materiały Warsztatów "Gospodarowanie zasobami - stan obecny i planowane zmiany. Nowe zasady gospodarki odpadami wydobywczymi", Katowice, 28-29.10.2008.

Koperski, T. and Lech, B. 2007. Produkcja kruszyw z odpadów powęglowych. Pr. Nauk. Inst. Górn. Pol. Wr. nr 119, s. 87-94.

Kucharzyk, P. 2004. Polsko-Węgierska Spółka Akcyjna „Haldex” - technologia zakładów przeróbki mechanicznej odpadów górniczych. Inżynieria Mineralna, 5(2), s. 60-64. 
Lutyński, A. and Blaschke, W. 2009. Aktualne kierunki zagospodarowania odpadów przeróbczych węgla kamiennego [W:] Materiaty Konferencji "Foresight w zakresie priorytetowych i innowacyjnych technologii zagospodarowywania odpadów pochodzacych z górnictwa węgla kamiennego”, Warszawa, 2.06.2009.

Mokrzycki, E., ed., 1992. Wykorzystanie odpadów pogórniczych węgla kamiennego [W:] Problemy kompleksowego wykorzystania surowców mineralnych. Studia i Rozprawy nr 22. Kraków: CPPGSMiE PAN.

Nowak, J. 2014. Wpływ stopnia termicznego przeobrażenia odpadów powęglowych na ich skład mineralny i petrograficzny. Gospodarka Surowcami Mineralnymi-Mineral Resources Management, 30(1), s. 143-160.

Potempa, M. and Szlugaj, J. 2007. Kierunki wykorzystania skał płonnych w KWK „Piast”. Pr. Nauk. Inst. Górn. Pol. Wr. nr 119, s. 159-171.

Smakowski et al. 2014 - Smakowski, T., Galos, K. and Ney, R. (ed.), 2014. Bilans gospodarki surowcami mineralnymi Polski i świata 2012. Wyd. PIG-PIB, Warszawa, 1171 s.

Sokół, W. and Tabor, A. 1996. Problemy zagospodarowania odpadów powęglowych z górnictwa węgla kamiennego. Przegl. Geol. 44, 7.

SPC 2014. Informator Stowarzyszenia Producentów Cementu - Przemyst cementowy w liczbach 2014. Kraków: Stowarzyszenie Producentów Cementu, 4 s.

Szlugaj et al. 2008 - Szlugaj, J., Galos, K. and Potempa, M. 2008. Możliwości produkcji kruszyw mineralnych w Kompanii Węglowej S.A. - Centrum Wydobywcze Wschód. Pr. Nauk. Inst. Górn. Pol. Wr. 121, s. $181-198$.

Szymkiewicz et al. 2009 - Szymkiewicz, A., Fraś, A. and Przystaś, R. 2009. Kierunki zagospodarowania odpadów wydobywczych w Południowym Koncernie Węglowym S.A. Wiadomości Górnicze, 60(7-8), s. 435-441.

Wróbel et al. 2012 - Wróbel, J., Fraś, A., Pierzchała, T., Przystaś, R., Machnik, A. and Hycnar, J. 2012. Konsolidacja działań Południowego Koncernu Węglowego S.A. ze spółkami energetycznymi Grupy TAURON w zakresie gospodarowania produktami ubocznymi [W:] Mat. XXVI Konferencji z cyklu "Zagadnienia Surowców Energetycznych i Energii w Gospodarce Krajowej”. Zakopane 14-17 października 2012. Kraków: IGSMiE, s. 113-127.

Zorychta, A. and Burtan, Z. 2008. Uwarunkowania i kierunki rozwoju technologii podziemnej eksploatacji złóż w polskim górnictwie węgla kamiennego. Gospodarka Surowcami Mineralnymi - Mineral Resources Management, 24(1/2), s. 53-70.

\title{
GOSPODARKA ODPADAMI Z GÓRNICTWA I PRZERÓBKI WĘGLA KAMIENNEGO W POLSCE
}

\author{
Słowa kluczowe
}

odpady powęglowe, kruszywa, odzysk węgla, Górny Śląsk

\section{Streszczenie}

Odpady z górnictwa i przeróbki stanowią największą grupę odpadów przemysłowych wytwarzanych i deponowanych w Polsce. Odpady z górnictwa i przeróbki węgla kamiennego tradycyjnie stanowią najważniejszą ich grupę. Obecnie są one wytwarzane w ilościach rzędu 29-33 mln Mg/r, przy wykorzystaniu gospodarczym rzędu $85 \%$. Odpady powęglowe dzieli się na dwie główne grupy: odpady górnicze (do 20\%) z górniczych prac przygotowawczych i udostępniających, oraz odpady przeróbcze: gruboziarniste ze wzbogacania w zawiesinowych cieczach ciężkich, drobnoziarniste ze wzbogacania w osadzarkach, bardzo drobnoziarniste odpady flotacyjne.

Wykorzystywane gospodarczo są głównie odpady gruboziarniste (zarówno górnicze, jak i przeróbcze). Główne kierunki ich zastosowań to: produkcja kruszyw do prac inżynierskich i budowy dróg, 
produkcja cementu i ceramiki budowlanej, odzysk węgla, stosowanie jako materiału podsadzkowego. W przypadku produkcji kruszyw, stosowane są dwa rodzaje odpadów: odpady powęglowe surowe oraz samoczynnie wypalony łupek powęglowy. Najważniejszym producentem kruszyw z odpadów powęglowych surowych jest Haldex S.A. z czterema zakładami przeróbczymi (dostarczającymi także łupek powęglowy do produkcji cementu lub ceramiki budowlanej, a także odzyskiwany węgiel) oraz dwoma węzłami krusząco-sortującymi. Łączna produkcja kruszyw w zakładach Haldex S.A. przekracza 3 miliony $\mathrm{Mg} / \mathrm{r}$. Produkcja kruszyw łupkoporytowych z łupka wypalonego jest prowadzona przez kilkanaście małych firm na łącznym poziomie ponad $0,5 \mathrm{mln} \mathrm{Mg} / \mathrm{r}$. Surowy łupek powęglowy znajduje zastosowanie do produkcji cementu i ceramiki budowlanej w ilości do 0,3 mln Mg/r. Odzysk węgla, prowadzony głównie w zakładach Haldex S.A., obecnie przekracza $0,15 \mathrm{mln} \mathrm{Mg} / \mathrm{r}$, podczas gdy produkcja granulowanych mułów węglowych w trzech instalacjach Haldex S.A. i dwóch instalacjach Tauron Wydobycie jest prawdopodobnie nawet kilka razy większa rzędu 0,6-0,7 mln Mg/r. W najbliższych latach nie należy się spodziewać wzrostu produkcji kruszyw łupkoporytowych, a także zużycia łupka surowego do produkcji cementu i ceramiki budowlanej. Dalszy wzrost jest natomiast możliwy w przypadku odzysku węgla z prowadzoną równolegle produkcją kruszyw z surowych odpadów powęglowych. Tym niemniej nie należy się spodziewać, że wszystkie wytworzone na tej drodze kruszywa znajdą zastosowanie gospodarcze, nawet na nasypy drogowe i obwałowania rzek w bliskim sąsiedztwie zakładów.

\section{MANAGEMENT OF HARD COAL MINING AND PROCESSING WASTES IN POLAND}

$$
\text { Key words }
$$

coal wastes, aggregates, coal recovery, Upper Silesia

$$
\text { Abstract }
$$

Mining and processing wastes comprise the largest group of industrial wastes generated and deposited in Poland. Among these, wastes from hard coal mining and processing traditionally constitute the most important group, currently generated at a level of 29-33 million Mg per year, with approx. $85 \%$ being utilised. Hard coal wastes are divided into two main groups - mining wastes (up to $20 \%$ ) coming from preparatory and productive mining works; and processing wastes categorized as coarse-grained wastes from dense, medium gravity separation, fine-grained wastes from jiggers, and very fine-grained flotation wastes.

Coarse-grained wastes (from both mining and processing) are the most economically useful. The main directions of their application are production of aggregates for engineering and road construction, production of cement or building ceramics, recovery of coal, or use as backfilling material. For aggregates production, two types of such wastes are used - raw coal wastes and self-burnt coal shale. The most important producer of aggregates from raw coal wastes is Haldex Co. with four processing plants (also delivering coal shale for cement or ceramics and recovered coal) and two crushing sieving units. Its total aggregates production exceeds 3 million $\mathrm{Mg}$ per year. Production of shale gravellite aggregates from self-burnt coal shale is carried out by a dozen or so small companies, with total production over 0.5 million $\mathrm{Mg}$ per year. Raw coal shale finds use in 
building ceramics and cement clinker manufacturing (up to 0.3 million $\mathrm{Mg}$ per year). Coal recovery, mostly in Haldex Co. plants, currently exceeds 0.15 million $\mathrm{Mg}$ per year, while granulated coal mud production in three plants of Haldex and two plants of Tauron Wydobycie can be a few times higher, ca. 0.6-0.7 million Mg per year. In the coming years, the production of shale gravellite aggregates and consumption of raw coal shale in cement and ceramics are not expected to rise. Further development is possible in the case of coal recovery accompanied by production of aggregates from raw coal wastes, though not all obtained aggregates will find use - not even for road embankments or river embankments in the immediate vicinity. 
